\title{
METHOD DEVELOPMENT AND VALIDATION OF ULTRAVIOLET-VISIBLE SPECTROSCOPIC METHOD FOR THE ESTIMATION OF ASSAY OF SUGAMMADEX SODIUM, APREMILAST, RIOCIGUAT, AND VORAPAXAR SULFATE DRUGS IN ACTIVE PHARMACEUTICAL INGREDIENT FORM
}

\author{
ASHOK CHAKRAVARTHY ${ }^{1 *}$, SAILAJA BBV ${ }^{1}$, PRAVEEN KUMAR A ${ }^{2}$ \\ ${ }^{1}$ Department of Inorganic and Analytical Chemistry, Andhra University, Vishakhapatnam - 530 003, Andhra Pradesh, India. ${ }^{2}$ Department \\ of Chemistry, Changwon National University, 641773 Changwon, South Korea. Email: mykingsenglish@gmail.com
}

Received: 03 October 2016, Revised and Accepted: 25 October 2016

ABSTRACT

Objective: The objective of this work is to develop a simple, efficient, and reproducible spectrophotometric method for the quantitative estimation of sugammadex sodium, apremilast, riociguat and vorapaxar sulfate drugs in its active pharmaceutical ingredient (API) form.

Methods: The developed ultraviolet-visible spectrophotometric method for the quantitative estimation of drugs - Sugammadex sodium, apremilast, riociguat and vorapaxar sulfate is based on measurement of absorption at a wavelength maximum $\left(\lambda_{\max }\right)$ of $210,230,323$, and $271 \mathrm{~nm}$ using water and methanol as diluents.

Results: The method was validated in terms of specificity, precision, linearity, accuracy, and robustness as per the ICH guidelines. The method was found to be linear in the range of 33-167\% for sugammadex sodium and apremilast drug substances; $50-150 \%$ for riociguat and vorapaxar sulfate drug substances. The percentage recovery values were in the range of $99.7-100.9 \%$ for sugammadex sodium, $99.3-100.3 \%$ for apremilast, 99.7-100.3\% for riociguat, and in the range of 99.5-100.3\% for vorapaxar sulfate at different concentration levels. Relative standard deviation for precision and intermediate precision results were found to be $<2 \%$. The correlation coefficient value observed for sugammadex sodium, apremilast, riociguat and vorapaxar sulfate drug substances was not $<0.99$ for their respective drugs. Results obtained from the validation experiments prove that the developed method is quantified for the estimation of assay of sugammadex sodium, apremilast, riociguat and vorapaxar sulfate drug substances.

Conclusion: The developed method can be successfully applied for routine analysis, quality control analysis and also suitable for stability analysis of assay of sugammadex sodium, apremilast, riociguat and vorapaxar sulfate in API form as per the regulatory requirements.

Keywords: Sugammadex sodium, Apremilast, Riociguat, Vorapaxar sulfate, Method development, Validation, Ultraviolet-visible spectrophotometry.

(C) 2017 The Authors. Published by Innovare Academic Sciences Pvt Ltd. This is an open access article under the CC BY license (http://creativecommons. org/licenses/by/4. 0/) DOI: http://dx.doi.org/10.22159/ajpcr.2017.v10i2.15502

\section{INTRODUCTION}

Chemical name of sugammadex is 6A, 6B, 6C, 6D, 6E, 6F, 6G, 6H-octakis$S$-(2-carboxyethyl)-6A, 6B, 6C, 6D, 6E, 6F, 6G, 6H-octathio- $\gamma$-cyclodextrin octasodium salt which is a modified $\gamma$-cyclodextrin. Cyclodextrins are cyclic dextrose units joined through 1-4 glycosyl bonds that are produced from starch or starch derivates using cyclodextrin glycosyltransferase. The three natural unmodified cyclodextrins consist of 6, 7 or 8 cyclic oligosaccharides and are called $\alpha$-, $\beta$ - or $\gamma$-cyclodextrin, respectively. $\alpha$-cyclodextrin, $\beta$-cyclodextrin, and $\gamma$-cyclodextrin are naturally occurring compounds derived from the degradation of starch by the glycosyltransferase enzyme. They can be formed naturally from bacteria or manufactured synthetically [1].

Sugammadex, a novel selective relaxant binding agent, is able to reverse both shallow and profound aminosteroid-induced neuromuscular blockade and has a unique mechanism of action that distinguishes it from cholinesterase inhibitors. It exerts no effect on acetylcholinesterases or on any receptor system in the body, thus eliminating the need for anticholinergic drugs and their undesirable adverse effects. In addition, the unique mechanism of reversal by encapsulation is independent of the depth of neuromuscular block; thus, reversal can be accomplished even during profound neuromuscular block [1].

These modifications resulted in a sugammadex compound (with a molecular weight of 2178) that is highly water soluble, with a hydrophobic cavity large enough to encapsulate steroidal neuromuscular blocking drugs, especially rocuronium. The aqueous solution of sugammadex has a $\mathrm{pH}$ of approximately 7.5. Sugammadex exerts its effect by forming very tight complexes at a 1:1 ratio with steroidal neuromuscular blocking agents (rocuronium $>$ vecuronium $>>$ pancuronium) [1]. The solubility of sugammadex in water is $26.6 \mathrm{mg} / \mathrm{ml}[2]$.

The active substance is a white to off-white octa-sodium salt powder which is highly but reversibly hygroscopic, freely soluble in water, and very slightly to slightly soluble in polar organic solvents [3]. Sugammadex sodium structure is shown in Fig. 1.

The chemical name of apremilast is $\mathrm{N}-[2-[(1 \mathrm{~S})-1-(3-\mathrm{ethoxy}-4-$ methoxyphenyl)-2-(methylsulfonyl)ethyl]-1,3-dioxo-2,3-dihydro-1Hisoindol-4-yl]acetamide and it is a drug for the treatment of certain types of psoriasis and psoriatic arthritis. It may also be useful for other immune system related inflammatory diseases. The drug acts as a selective inhibitor of the enzyme phosphodiesterase 4 and inhibits spontaneous production of tumor necrosis factor-alpha from human rheumatoid synovial cells [4].

Apremilast was approved by the United States Food and Drug Administration (US-FDA) in March 2014 for the treatment of adults with active psoriatic arthritis. Apremilast is the first oral agent that is FDAapproved for the treatment of psoriatic arthritis and offers the convenience 
of oral dosing compared to treatment with biopharmaceuticals. In September 2014, the US-FDA approved apremilast for the treatment of moderate to severe plaque psoriasis. It is also being tested for its efficacy in treating other chronic inflammatory diseases such as ankylosing spondylitis, Behcet's disease, and rheumatoid arthritis [4].

Apremilast is a white to pale yellow non-hygroscopic powder with a melting point of approximately $156.1^{\circ} \mathrm{C}$. It is practically insoluble in water, slightly soluble in ethanol, and soluble in acetone. Apremilast is the S-enantiomer with a specific rotation of $+28.1^{\circ}$ in acetonitrile at a concentration of $20 \mathrm{mg} / \mathrm{mL}$ [5]. Apremilast structure is shown in Fig. 2.

The chemical name of riociguat is methyl 4,6-diamino-2-[1-(2fluorobenzyl)-1H-pyrazo-lo[3,4-b]pyridin-3-yl]-5-pyrimidinyl(methyl) carbamate. Riociguat (trade name Adempas) is a novel drug (by Bayer) that is a stimulator of soluble guanylate cyclase (sGC). Clinical trials have looked at riociguat as a new approach to treat two forms of pulmonary hypertension (PH): Chronic thromboembolic $\mathrm{PH}$ and pulmonary arterial hypertension. Riociguat constitutes the first drug of a novel class of sGC stimulators [6]

Riociguat is a white to yellowish crystalline powder, not hygroscopic. It is practically insoluble in water and shows a strong $\mathrm{pH}$-dependent solubility in aqueous media with a maximum around $\mathrm{pH} 2$, slightly soluble in acetone and methanol and freely soluble in dimethylsulfoxide and dimethylformamide [7]. Riociguat structure is shown in Fig. 3.

Vorapaxar sulfate (brand name Zontivity, formerly known as SCH 530348) is a thrombin receptor (protease-activated receptor) antagonist based on the natural product himbacine, discovered by Schering-Plough and developed by Merck \& Co. Vorapaxar sulfate is used

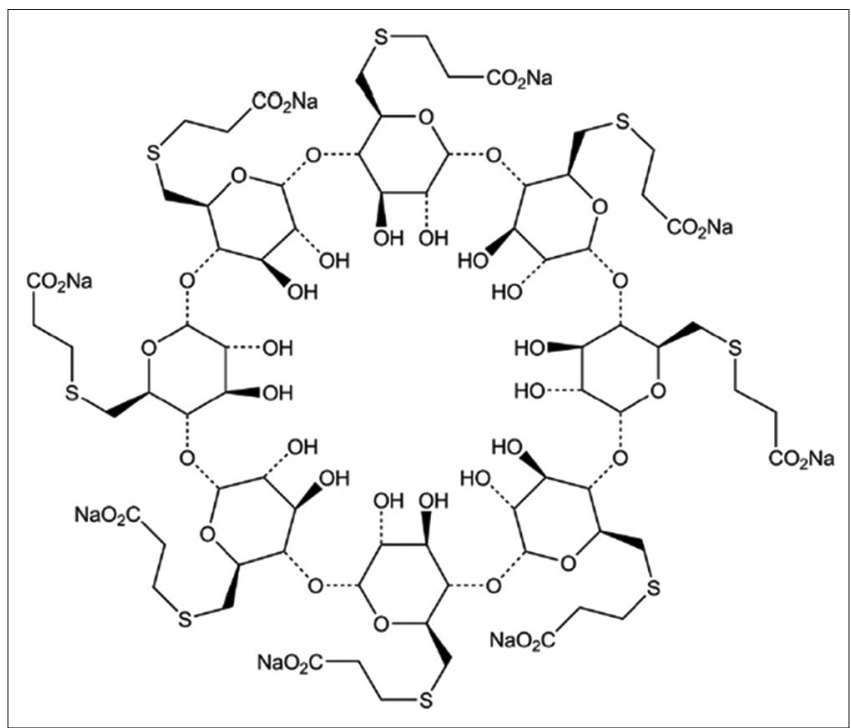

Fig. 1: Structure of sugammadex sodium

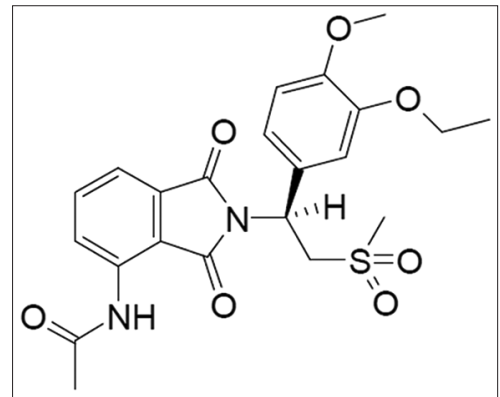

Fig. 2: Structure of apremilast for persons with a history of myocardial infarction (MI) (heart attack) or persons with peripheral arterial disease. Studies have shown that this medication can reduce the rate of combined endpoint cardiovascular death, MI, stroke, and urgent coronary revascularization [8].

Vorapaxar sulfate (Zontivity) is a medicine used to reduce the occurrence of atherothrombotic events (problems caused by blood clots and hardening of the arteries) such as heart attacks or strokes in adult patients who have already had a heart attack or who have peripheral arterial disease (problem with blood flow in the arteries) with symptoms. It is given in combination with aspirin (acetylsalicylic acid) and where appropriate with a third medicine, clopidogrel, both of which also help prevent atherothrombotic events [9]

The chemical name of the active substance vorapaxar sulfate is ethyl[(1R,3aR,4aR,6R,8aR,9S,9aS)- -9-\{(1E)-2-[5-(3-fluorophenyl)pyridin2-yl] ethen-1-yl\}-1-methyl-3-oxododecahydronaphtho[2,3-c]furan-6-yl] carbamate sulfate, corresponding to the molecular formula $\mathrm{C}_{29} \mathrm{H}_{33} \mathrm{FN}_{2} \mathrm{O}_{4}$ - $\mathrm{H}_{2} \mathrm{SO}_{4}$ and has a relative molecular mass 590.7. It appears as a white to off-white, slightly hygroscopic, crystalline powder. It is freely soluble in methanol and slightly soluble in ethanol and acetone but insoluble to practically insoluble in aqueous solutions at $\mathrm{pH}$ above 3.0. The highest solubility in aqueous solution can be achieved at $\mathrm{pH} 1.0$ or in simulated gastric fluids at $\mathrm{pH}$ 1.4. The dissociation constant of vorapaxar sulfate was determined to be $\mathrm{pKa}=4.7$ and its partition coefficient $\log \mathrm{P}$ was determined to be 5.1 [10]. Vorapaxar sulfate structure is shown in Fig. 4.

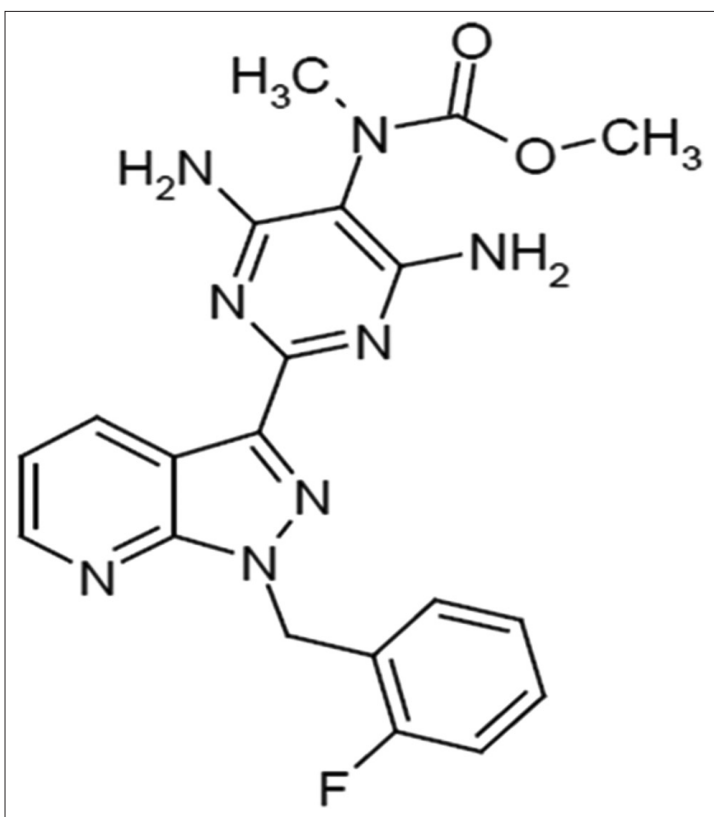

Fig. 3: Structure of riociguat

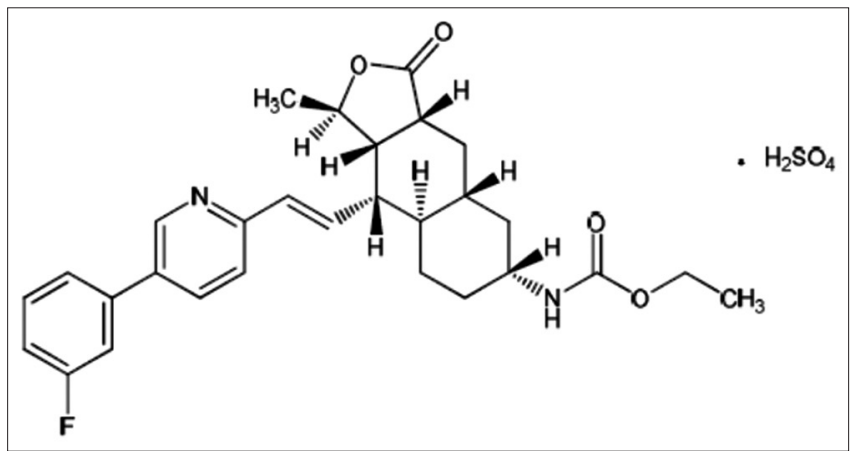

Fig. 4: Structure of vorapaxar sulfate 
From the literature survey, it is evident that very few research articles are available for sugammadex sodium, apremilast, riociguat and for vorapaxar sulfate drug substances. Kaihe et al. published an article on identification, characterization and high performance liquid chromatography (HPLC) quantification of impurities in apremilast [11]. Sirisha et al. published an article on method development and validation of riocugat by reversed phase-HPLC [12].

Analytical methods are not available in USP [13] and European Pharmacopoeia [14] for the quantitative determination of sugammadex sodium, apremilast, riociguat and vorapaxar sulfate drugs. The present research work describes the estimation of assay content of sugammadex sodium, apremilast, riociguat and vorapaxar sulfate in active pharmaceutical ingredient (API) form using ultraviolet (UV)-visible spectrophotometry technique. Developed method gives a sensitive, specific, and economical method for the determination of sugammadex sodium, apremilast, riociguat and vorapaxar sulfate in very short time using UV-visible spectrophotometer. Water for sugammadex sodium and methanol for apremilast, riociguat, and vorapaxar sulfate were used in diluent preparation based on the drug solubility properties of their respective drugs. Developed UV-visible spectrophotometric method was validated with respect to specificity, linearity, precision, accuracy, and robustness parameters.

\section{METHODS}

Qualified standards (sugammadex sodium $\sim 99.9 \%$, apremilast $\sim 99.9 \%$, riociguat $\sim 99.9 \%$, vorapaxar sulfate $\sim 100.0 \%$ ) and samples are obtained from Spectrum Pharma Research Solutions and were used without any further purification. HPLC grade methanol (MeOH purity $\sim 99.8 \%$ ) and water were obtained from Rankem (India).

\section{Instrumentation}

A double beam UV-visible spectrophotometer (Shimadzu, model 1800) having two matched quartz cells with $1 \mathrm{~cm}$ light path length and loaded with UV probe software was used for the recording of spectra and measuring absorbance for method development and validation study.

\section{Method development}

\section{Selection of diluent}

Water was used as diluent for the preparation of standards and samples of sugammadex sodium and methanol was used as diluent for the preparation of standards and samples of apremilast, riociguat and vorapaxar sulfate drug substances based on the solubility characteristics of the drug substances.

\section{Selection of suitable wavelength detection}

Spectra for sugammadex sodium, apremilast, riociguat, and vorapaxar sulfate were measured from 200 to $800 \mathrm{~nm}$ for wavelength maxima by recording UV-visible spectrum of standard solution. The corresponding spectrum of sugammadex sodium, apremilast, riociguat, and vorapaxar sulfate is shown in Figs. 5-8. Maximum absorbance $\left(\lambda_{\max }\right)$ was shown at $210,230,323$ and $271 \mathrm{~nm}$ for standard solution of sugammadex sodium, apremilast, riociguat and vorapaxar sulfate, respectively. Based on the spectra maxima - 210, 230, 323, and $271 \mathrm{~nm}$ were selected for identification and quantification of sugammadex sodium, apremilast, riociguat, and vorapaxar sulfate drug substances.

\section{Preparation of standard and sample solutions for sugammadex} sodium

Accurately weighed and transferred $50 \mathrm{mg}$ of sugammadex sodium working standard into a $50 \mathrm{ml}$ volumetric flask. Added about $30 \mathrm{ml}$ of water (diluent) and sonicated to dissolve with intermittent shaking. The resulting solution is diluted up to the mark with diluent and mixed well.

\section{Preparation of standard solution}

Transferred $3 \mathrm{ml}$ of standard stock solution of sugammadex sodium into a $25 \mathrm{ml}$ volumetric flask and diluted up to the mark with the diluent and mixed well.

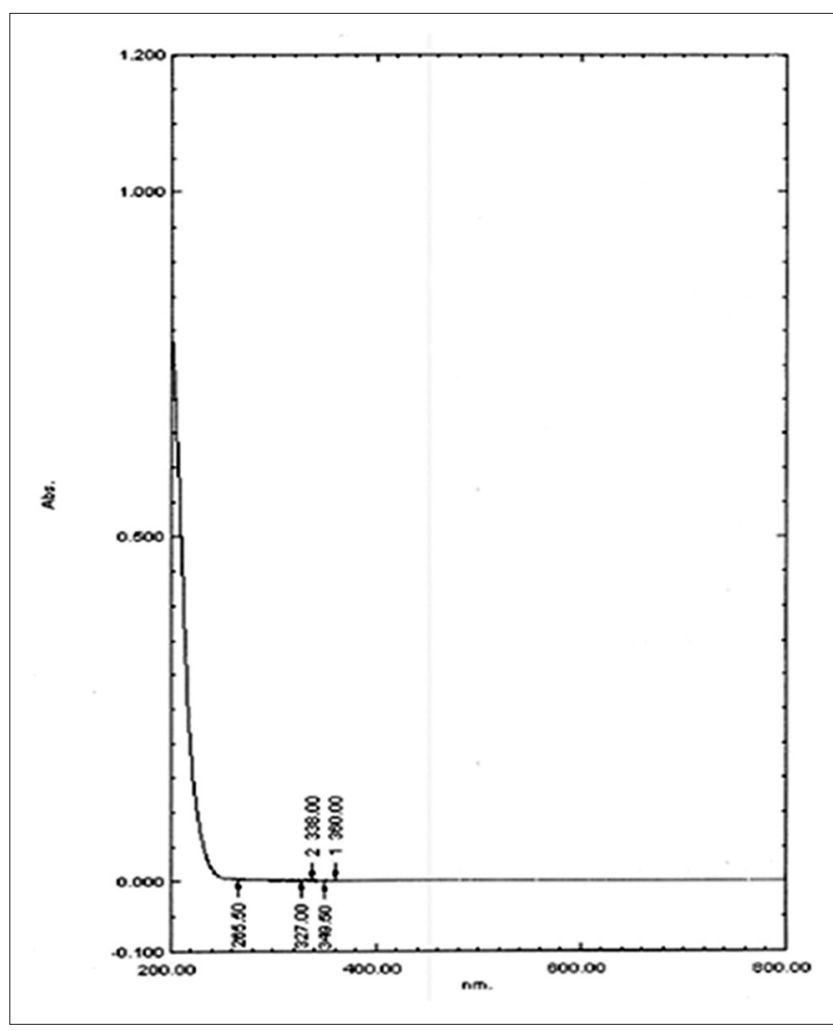

Fig. 5: Sugammadex sodium standard spectrum

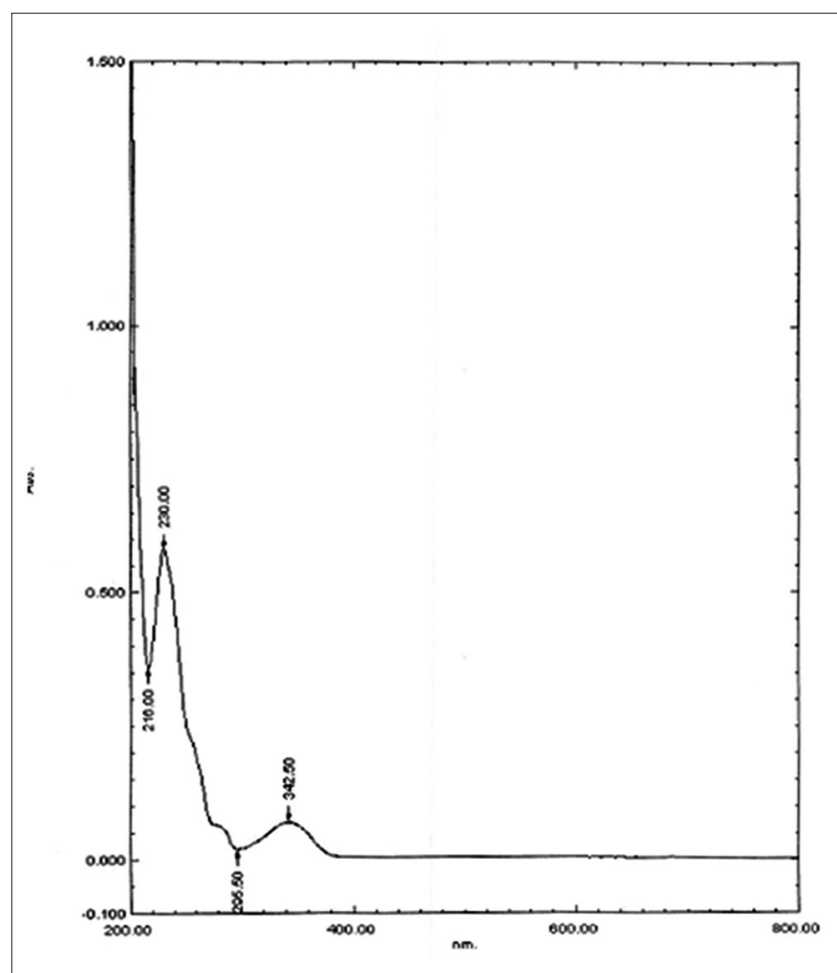

Fig. 6: Apremilast standard spectrum 


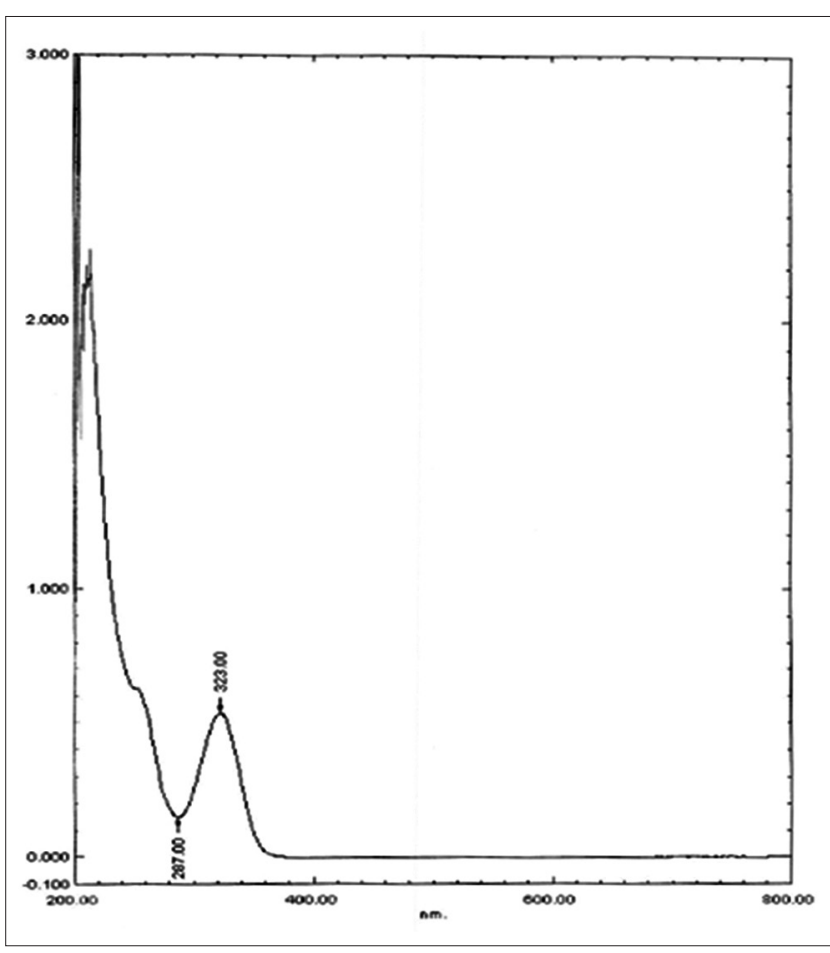

Fig. 7: Riociguat standard spectrum

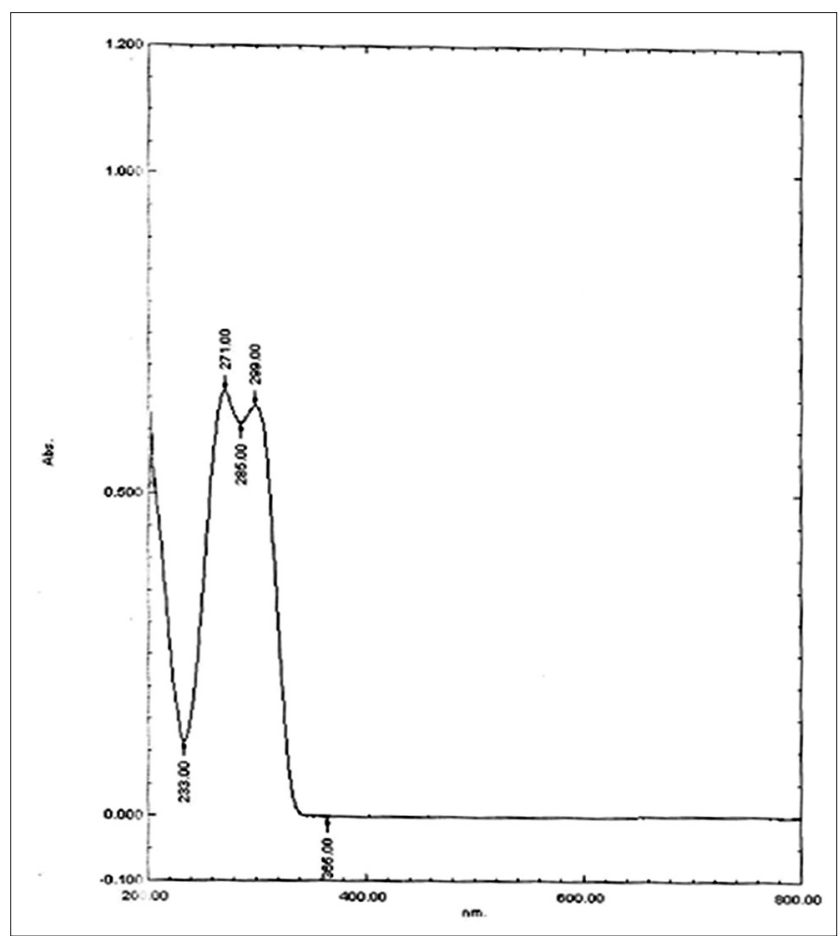

Fig. 8: Vorapaxar sulfate standard spectrum

\section{Preparation of sample solution}

Accurately weighed and transferred $50 \mathrm{mg}$ of sugammadex sodium drug substance into a $50 \mathrm{ml}$ volumetric flask. Added about $30 \mathrm{ml}$ of water (diluent) and sonicated to dissolve with intermittent shaking. The resulting solution is diluted up to the mark with diluent and mixed well. Further, diluted $3 \mathrm{ml}$ of sugammadex sodium sample stock solution into a $25 \mathrm{ml}$ volumetric flask and diluted up to the mark with the diluent and mixed well. Transferred the resultant sample solution into UV cuvettes for analysis.
Preparation of standard and sample solutions for apremilast Standard stock solution of apremilast

Accurately weighed and transferred $50 \mathrm{mg}$ of apremilast working standard into a $50 \mathrm{ml}$ volumetric flask. Added about $30 \mathrm{ml}$ of methanol (diluent) and sonicated to dissolve with intermittent shaking. The resulting solution is diluted up to the mark with diluent and mixed well.

\section{Preparation of standard solution}

Transferred $0.3 \mathrm{ml}$ of standard stock solution of apremilast into a $50 \mathrm{ml}$ volumetric flask and diluted up to the mark with the diluent and mixed well.

\section{Preparation of sample solution}

Accurately weighed and transferred $50 \mathrm{mg}$ of apremilast drug substance into a $50 \mathrm{ml}$ volumetric flask. Added about $30 \mathrm{ml}$ of methanol (diluent) and sonicated to dissolve with intermittent shaking. The resulting solution is diluted up to the mark with diluent and mixed well. Further, diluted $0.3 \mathrm{ml}$ of apremilast sample stock solution into a $50 \mathrm{ml}$ volumetric flask and diluted up to the mark with the diluent and mixed well. Transferred the resultant sample solution into UV cuvettes for analysis.

\section{Preparation of standard and sample solutions for riociguat} Standard stock solution of riociguat

Accurately weighed and transferred $50 \mathrm{mg}$ of riociguat working standard into a $50 \mathrm{ml}$ volumetric flask. Added about $30 \mathrm{ml}$ of methanol (diluent) and sonicated to dissolve with intermittent shaking. The resulting solution is diluted up to the mark with diluent and mixed well.

\section{Preparation of standard solution}

Transferred $0.4 \mathrm{ml}$ of standard stock solution of riociguat into a $25 \mathrm{ml}$ volumetric flask and diluted up to the mark with the diluent and mixed well.

\section{Preparation of sample solution}

Accurately weighed and transferred $50 \mathrm{mg}$ of riociguat drug substance into a $50 \mathrm{ml}$ volumetric flask. Added about $30 \mathrm{ml}$ of methanol (diluent) and sonicated to dissolve with intermittent shaking. The resulting solution is diluted up to the mark with diluent and mixed well. Further, diluted $0.4 \mathrm{ml}$ of riociguat sample stock solution into a $25 \mathrm{ml}$ volumetric flask and diluted up to the mark with the diluent and mixed well. Transferred the resultant sample solution into UV cuvettes for analysis.

Preparation of standard and sample solutions for vorapaxar sulfate

\section{Standard stock solution of vorapaxar sulfate}

Accurately weighed and transferred $50 \mathrm{mg}$ of vorapaxar sulfate working standard into a $50 \mathrm{ml}$ volumetric flask. Added about $30 \mathrm{ml}$ of methanol (diluent) and sonicated to dissolve with intermittent shaking. The resulting solution is diluted up to the mark with diluent and mixed well.

\section{Preparation of standard solution}

Transferred $0.4 \mathrm{ml}$ of standard stock solution of vorapaxar sulfate into a $25 \mathrm{ml}$ volumetric flask and diluted up to the mark with the diluent and mixed well.

\section{Preparation of sample solution}

Accurately weighed and transferred $50 \mathrm{mg}$ of vorapaxar sulfate drug substance into a $50 \mathrm{ml}$ volumetric flask. Added about $30 \mathrm{ml}$ of methanol (diluent) and sonicated to dissolve with intermittent shaking. The resulting solution is diluted up to the mark with diluent and mixed well. Further, diluted $0.4 \mathrm{ml}$ of vorapaxar sulfate sample stock solution into a $25 \mathrm{ml}$ volumetric flask and diluted up to the mark with the diluent and mixed well. Transferred the resultant sample solution into UV cuvettes for analysis. 


\section{Method validation}

\section{Specificity/stress studies}

Specificity is the ability to assess unequivocally the analyte in the presence of components which may be expected to be present. Typically, these might include impurities, degradants, and matrix [15]. The specificity of the developed method was established to prove the absence of interference from diluent absorbance which is part of required pharmaceutical drug substance preparation.

\section{Linearity}

Linearity is the ability of the method to obtain results which are either directly or after mathematical transformation proportional to the concentration of the analyte within a given range. The linearity of response for sugammadex sodium, apremilast, riociguat, and vorapaxar sulfate were determined in the range from $33 \%$ to $167 \%$ for sugammadex sodium and apremilast drug substances; 50$150 \%$ for riociguat and vorapaxar sulfate drug substances. The five concentrations of each component were subjected to regression analysis by least squares method to calculate correlation coefficient and calibration equation. The method of linear regression was used for the data evaluation.

\section{Precision}

Precision is a measure of the reproducibility of the whole analytical method under normal operating conditions. The precision was expressed as the relative standard deviation (RSD).

$\% \mathrm{RSD}=($ Standard deviation $/$ average $) \times 100$

Precision of the developed method was carried out by six determinations (preparations) of the test solution by measuring the absorbance of test solution and calculated the \% RSD for estimation of drug content.

\section{Accuracy}

Accuracy or trueness was determined by applying the method to samples in which known amounts of analyte have been added. These should be analyzed against standard and blank solutions to ensure that no interference exists. The accuracy was calculated from the test results as a percentage of the analyte recovered by the assay.

Accuracy of the present method was carried out using the drug substance spiked solution at three different concentration levels of $33 \%, 100 \%$ and $167 \%$ for sugammadex sodium and for apremilast; $50 \%, 100 \%$ and $150 \%$ levels for riociguat and for vorapaxar sulfate drug substances, in triplicate determinations. Percent recovery and the mean percentage recovery were calculated for sugammadex sodium, apremilast, riociguat, and vorapaxar sulfate drug substances.

\section{Robustness}

Robustness of the method indicates the reliability of analysis to assess the system suitability parameters under the influence of small but deliberate variations in method parameters. Robustness was performed by changing the detection wavelength $\pm 2 \mathrm{~nm}$ to the wavelength maximum $\left(\lambda_{\text {max }}\right)$ and calculating the $\%$ assay and \% RSD for the test solution.

\section{Solution stability}

Sugammadex sodium, apremilast, riociguat, and vorapaxar sulfate sample solutions and the standard solutions were prepared as per the test procedure. All these solutions were divided into two portions. One portion was stored at room temperature (RT) and the other portion was stored in the refrigerator at $2-8^{\circ} \mathrm{C}$. Freshly prepared solutions and the solutions which were stored at RT and in refrigerator $\left(2-8^{\circ} \mathrm{C}\right)$ up to 24 hrs were measured for absorbance at different time intervals. The $\%$ assay obtained at initial was compared with the $\%$ assay obtained at different time intervals.

\section{RESULTS AND DISCUSSION}

Optimization of UV-visible spectrophotometric method conditions The main purpose of the current method is to develop a simple, sensitive and precise UV-visible spectrophotometric method for the estimation of sugammadex sodium, apremilast, riociguat, and vorapaxar sulfate for the routine quantitative determination of samples which will reduce tedious sample preparations, cost of materials and manpower required to perform the analysis. Apremilast, riociguat, and vorapaxar sulfate are UV-absorbing molecules with specific chromophores in the structure that absorb at a particular wavelength, and this absorbance was successfully employed for their quantitative determinations using the UV spectroscopic method. Chromophore is not seen in the structure of drug substance - Sugammadex sodium, however, the molecule shows good absorbance at lower wavelength of UV region. The spectral analysis showed that the $\lambda_{\max }$ for sugammadex sodium, apremilast, riociguat and vorapaxar sulfate are at 210, 230, 323 and $271 \mathrm{~nm}$, respectively. Water was selected as diluent for the standard and sample solutions of sugammadex sodium and methanol was selected for the standard and sample solutions of apremilast, riociguat, and vorapaxar sulfate drug substances. Thus, the developed UV-visible Spectroscopic method for the analysis of sugammadex sodium, apremilast, riociguat, and vorapaxar sulfate in its API form enables analysis of several samples at the same time due to its simplicity in performing the analysis.

The UV-visible spectra of blank run for water, blank run for methanol, sugammadex sodium standard solution (concentration - $120 \mu \mathrm{g} / \mathrm{mL}$ ), sugammadex sodium sample solution (concentration - $120 \mu \mathrm{g} / \mathrm{mL}$ ), apremilast standard solution (concentration - $6 \mu \mathrm{g} / \mathrm{mL}$ ), apremilast sample solution (concentration - $6 \mu \mathrm{g} / \mathrm{mL}$ ), riociguat standard solution (concentration - $16 \mu \mathrm{g} / \mathrm{mL}$ ), riociguat sample solution (concentration - $16 \mu \mathrm{g} / \mathrm{mL}$ ), vorapaxar sulfate standard solution (concentration - $16 \mu \mathrm{g} / \mathrm{mL}$ ), and vorapaxar sulfate sample solution (concentration - $16 \mu \mathrm{g} / \mathrm{mL}$ ) are shown in Figs. 5-14.

\section{Method validation}

The objective of validation of an analytical procedure is to demonstrate that it is suitable for its intended use. The described UV-visible spectrophotometric method for the estimation of sugammadex sodium, apremilast, riociguat, and vorapaxar sulfate has been extensively validated for identification and quantification of its drug substances as per ICH guidelines [15]. After successful completion of method development $[16,17]$, method validation $[15,18-20]$ was performed to ensure that the developed method was capable of giving reproducible and reliable results when used by different operators employed on the same equipment of the same laboratory or of different laboratories. The developed UV-visible spectrophotometric method was validated to quantify sugammadex sodium, apremilast, riociguat, and vorapaxar sulfate in its API form by determining the parameters including specificity, precision, linearity, accuracy and robustness according to the ICH guidelines.

\section{Specificity}

Specificity of the developed method was performed by scanning the UV-visible spectra of diluent, standard and sample solutions of sugammadex sodium, apremilast, riociguat and vorapaxar sulfate from 200 to $800 \mathrm{~nm}$. Furthermore, spectral homogeneity of sugammadex sodium, apremilast, riociguat, and vorapaxar sulfate control samples, found to be similar with those obtained for the standard solutions of sugammadex sodium, apremilast, riociguat, and vorapaxar sulfate.

\section{Precision}

Method precision was determined by analyzing the test solution of six determinations and the observed values of \% RSD were shown in Tables 1 and 2. \% RSD for sugammadex sodium, apremilast, riociguat, and vorapaxar sulfate compounds in test solution for six determinations was not more than $2.0 \%$. Intermediate precision of the method was studied by analyzing the test solution of six determinations, and the 


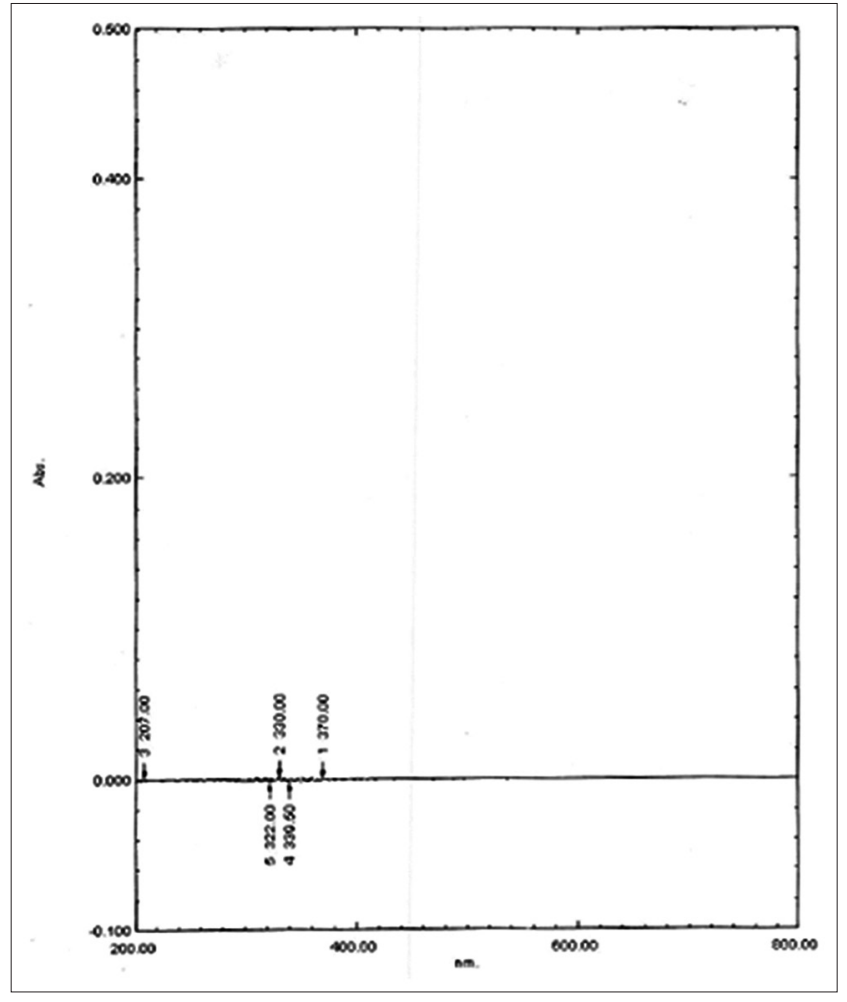

Fig. 9: Blank spectrum of water

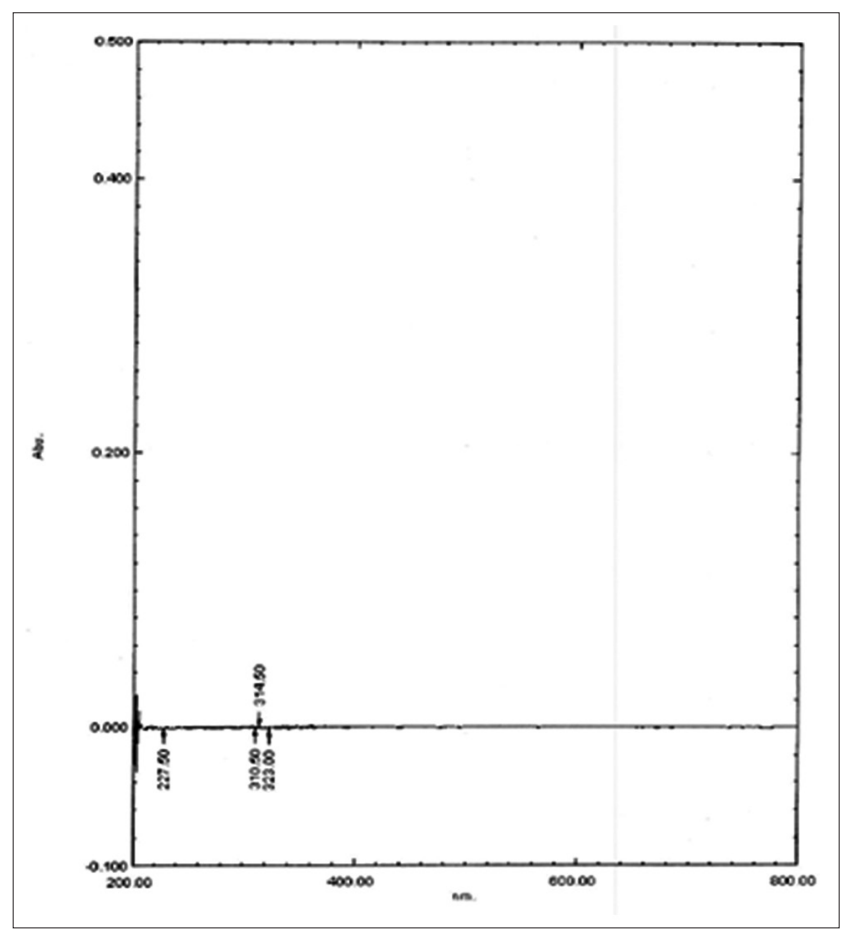

Fig. 10: Blank spectrum of methanol

observed results were shown in Tables 1 and 2 . The \% RSD difference between the two analysts is $0.1 \%, 0.1 \%, 0.0 \%$ and $0.1 \%$ for sugammadex sodium, apremilast, riociguat, and vorapaxar sulfate, respectively. Less difference between the two analysts shows that the developed method is precise and has good intermediate precision.

\section{Linearity}

The linearity graphs were plotted between the absorbance versus concentration to obtain the calibration curve. Linearity graphs for

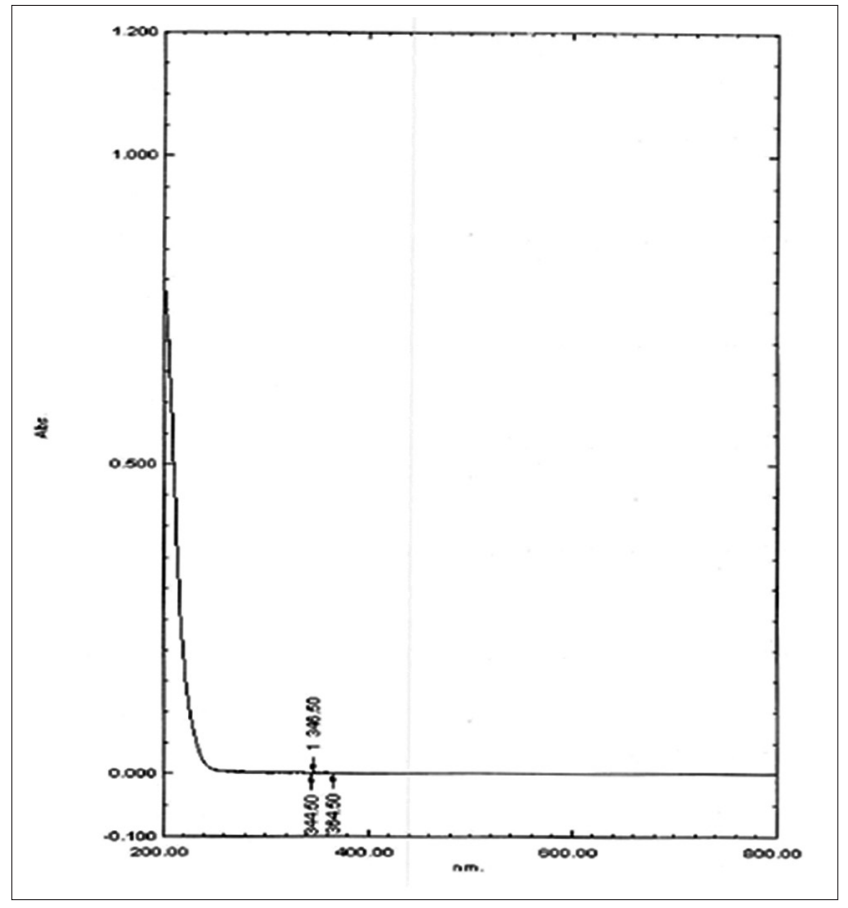

Fig. 11: Sugammadex sodium sample spectrum

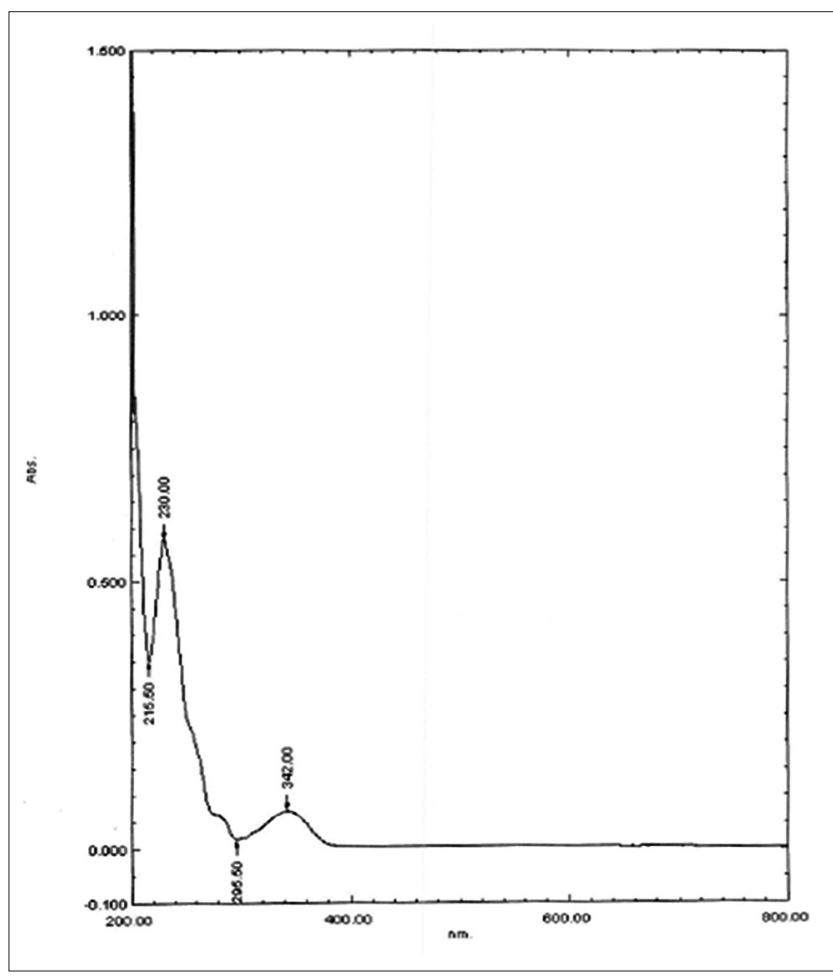

Fig. 12: Apremilast sample spectrum

sugammadex sodium, apremilast, riociguat, and vorapaxar sulfate were shown in Figs. 15-18. The response obtained for sugammadex sodium, apremilast, riociguat, and vorapaxar sulfate was found to be linear in the range of $33-167 \%$ for sugammadex sodium and apremilast; $50-150 \%$ for riociguat and vorapaxar sulfate drug substances. The correlation coefficient observed for sugammadex sodium, apremilast, riociguat and vorapaxar sulfate compounds was not $<0.99$ and also statistical values of all compounds were shown in Table 3. Results demonstrate that an excellent correlation between the absorbance and concentration of sugammadex sodium, apremilast, riociguat, and vorapaxar sulfate drug substances. 
Table 1: Precision and intermediate precision data of sugammadex sodium, apremilast

\begin{tabular}{|c|c|c|c|c|}
\hline \multirow[t]{2}{*}{ Determination } & \multicolumn{2}{|c|}{ For sugammadex sodium } & \multicolumn{2}{|l|}{ For apremilast } \\
\hline & $\begin{array}{l}\text { Method precision } \\
\text { (\% Assay) }\end{array}$ & $\begin{array}{l}\text { Intermediate precision } \\
\text { (\% Assay) }\end{array}$ & $\begin{array}{l}\text { Method precision } \\
\text { (\% Assay) }\end{array}$ & $\begin{array}{l}\text { Intermediate precision } \\
\text { (\% Assay) }\end{array}$ \\
\hline Determination-1 & 100.2 & 99.6 & 100.0 & 100.0 \\
\hline Determination-2 & 99.7 & 99.6 & 99.7 & 99.8 \\
\hline Determination-3 & 100.3 & 99.8 & 100.1 & 99.9 \\
\hline Determination-4 & 99.8 & 100.3 & 100.5 & 100.3 \\
\hline Determination-5 & 100.5 & 99.7 & 100.0 & 100.0 \\
\hline Determination-6 & 99.8 & 100.0 & 99.9 & 99.8 \\
\hline Average & 100.05 & 99.82 & 100.03 & 99.98 \\
\hline SD & 0.33 & 0.26 & 0.26 & 0.17 \\
\hline$\%$ RSD & 0.33 & 0.26 & 0.26 & 0.17 \\
\hline
\end{tabular}

SD: Standard deviation, RSD: Relative standard deviation

Table 2: Precision and intermediate precision data of riociguat and vorapaxar sulfate

\begin{tabular}{|c|c|c|c|c|}
\hline \multirow[t]{2}{*}{ Determination } & \multicolumn{2}{|l|}{ For riociguat } & \multicolumn{2}{|c|}{ For vorapaxar sulfate } \\
\hline & $\begin{array}{l}\text { Method precision } \\
\text { (\% Assay) }\end{array}$ & $\begin{array}{l}\text { Intermediate precision } \\
\text { (\% Assay) }\end{array}$ & $\begin{array}{l}\text { Method precision } \\
\text { (\% Assay) }\end{array}$ & $\begin{array}{l}\text { Intermediate precision } \\
\text { (\% Assay) }\end{array}$ \\
\hline Determination-1 & 99.9 & 99.9 & 100.1 & 100.3 \\
\hline Determination-2 & 99.9 & 99.7 & 99.9 & 100.4 \\
\hline Determination-3 & 100.1 & 99.9 & 100.3 & 100.0 \\
\hline Determination-4 & 99.7 & 99.8 & 100.4 & 100.2 \\
\hline Determination-6 & 100.0 & 99.6 & 99.8 & 100.2 \\
\hline Average & 99.95 & 99.83 & 100.06 & 100.18 \\
\hline SD & 0.15 & 0.16 & 0.26 & 0.13 \\
\hline$\%$ RSD & 0.15 & 0.16 & 0.26 & 0.13 \\
\hline
\end{tabular}

SD: Standard deviation, RSD: Relative standard deviation

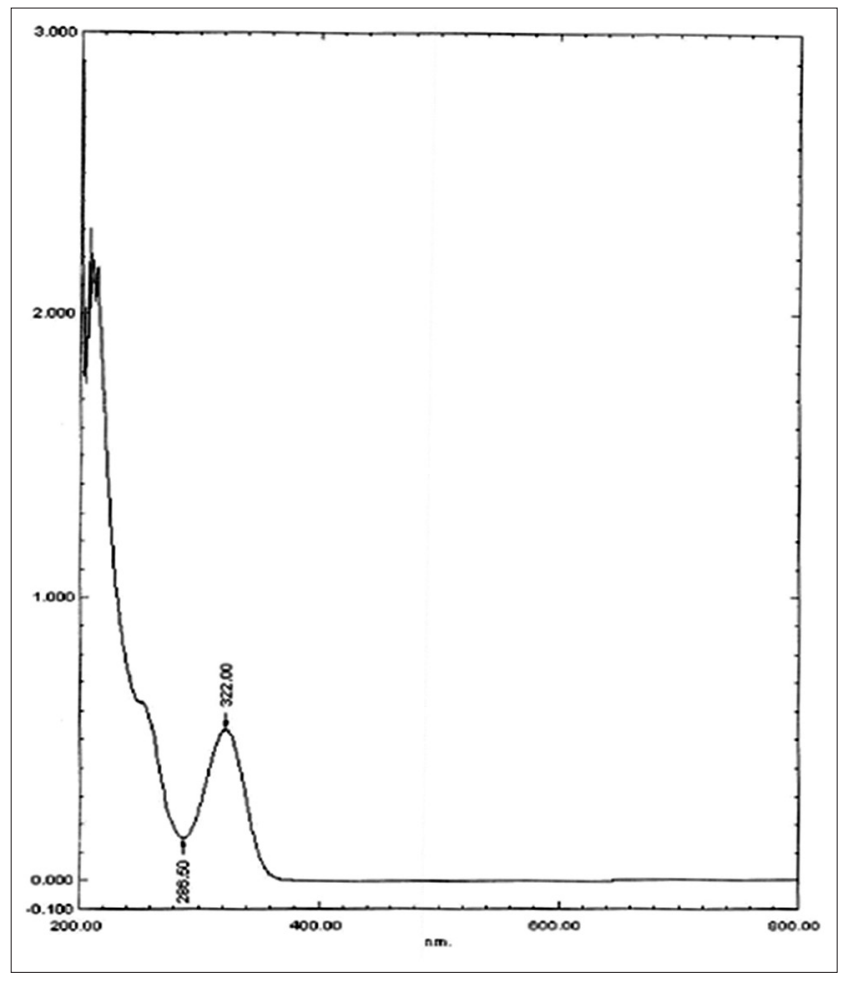

Fig. 13: Riociguat sample spectrum

\section{Accuracy}

The percentage recovery results for sugammadex sodium, apremilast, riociguat, and vorapaxar sulfate were varied from $99.7 \%$ to $100.9 \%$, $99.3 \%$ to $100.3 \%, 99.7 \%$ to $100.3 \%$ and $99.5 \%$ to $100.3 \%$, respectively,

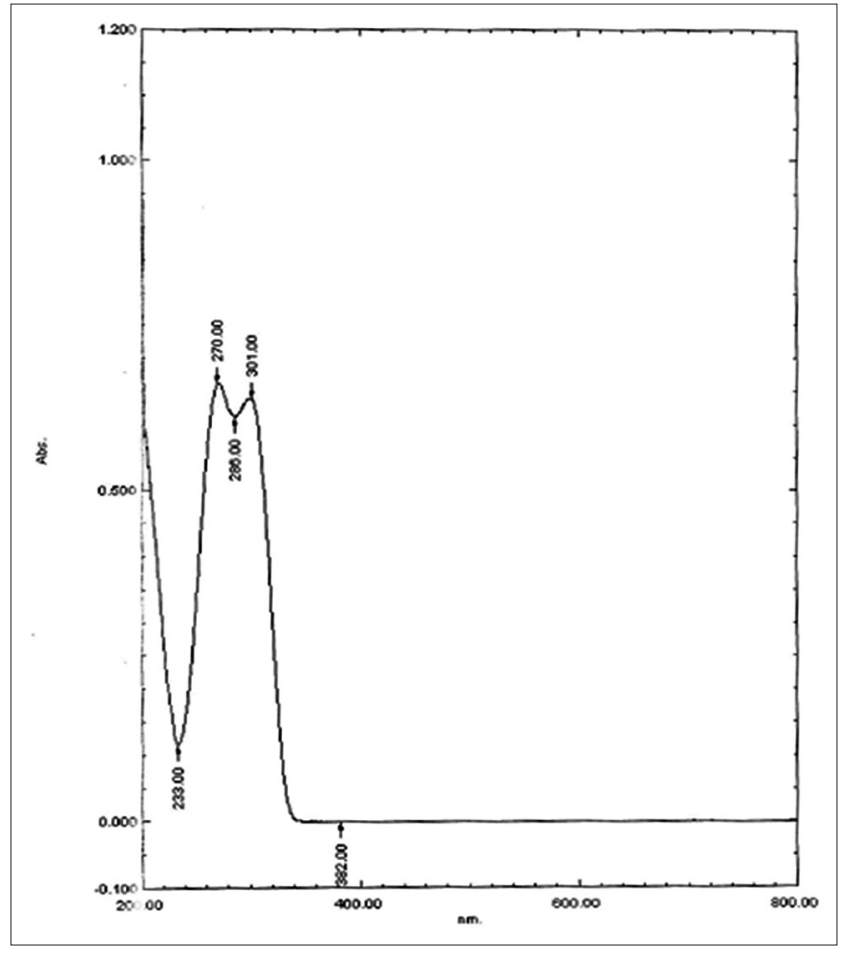

Fig. 14: Vorapaxar sulfate sample spectrum

at three different concentration levels, and the results were shown in Tables 4 and 5 . Based on the \% recovery data, it was concluded that the developed method is capable for the estimation of sugammadex sodium, apremilast, riociguat, and vorapaxar sulfate drug substances and is adequate for routine analysis. 


\section{Robustness}

The robustness of the proposed method was performed by preparing the standard solutions and test solutions of sugammadex sodium, apremilast, riociguat, and vorapaxar sulfate at 100\% level and was analyzed by a change in wavelength for absorbance readings. The wavelength selected was $\pm 2 \mathrm{~nm}$ to the $\lambda_{\max }$, i.e., 208 and $212 \mathrm{~nm}$ for sugammadex sodium, 228 and $232 \mathrm{~nm}$ for apremilast, 321 and $325 \mathrm{~nm}$ for riociguat, 269 and $273 \mathrm{~nm}$ for vorapaxar sulfate respectively for standard and sample solutions. In the robustness condition (wavelength variation of $\pm 2 \mathrm{~nm}$ to the $\lambda_{\max }$ ), the assay values of sugammadex sodium, apremilast, riociguat, and vorapaxar sulfate were not $<99 \%$. \% Assay results for robustness parameters were shown in Tables 6 and 7 .

\section{Solution stability}

The percent assay value difference was determined for solutions stored at RT and at refrigerated condition $\left(2-8^{\circ} \mathrm{C}\right)$ for different time intervals up to $24 \mathrm{hrs}$. Sugammadex sodium, apremilast, riociguat, and vorapaxar sulfate absorbances were found to be stable up to $24 \mathrm{hrs}$ at RT and also at refrigerator condition. Solution stability results at RT and refrigerated condition were shown in Table 8.

Table 3: Optical characteristics and linearity data

\begin{tabular}{|c|c|c|c|c|}
\hline Parameter & $\begin{array}{l}\text { Sugammadex } \\
\text { sodium }\end{array}$ & Apremilast & Riociguat & $\begin{array}{l}\text { Vorapaxar } \\
\text { sulfate }\end{array}$ \\
\hline Detection wavelength $\left(\lambda_{\max }\right)$ & $210 \mathrm{~nm}$ & $230 \mathrm{~nm}$ & $323 \mathrm{~nm}$ & $271 \mathrm{~nm}$ \\
\hline Beer's law limits $(\mu \mathrm{g} / \mathrm{ml})$ & $40-200$ & $2-10$ & $8-24$ & $8-24$ \\
\hline \multicolumn{5}{|l|}{ Regression statistics } \\
\hline Slope & 0.0041 & 0.0974 & 0.0324 & 0.0408 \\
\hline Intercept & 0.0026 & 0.0016 & 0.0121 & 0.0076 \\
\hline Correlation coefficient & 1.0000 & 1.0000 & 0.9997 & 1.0000 \\
\hline Intercept at 95\% confidence interval (lower value-upper value) & $0.00973-0.00460$ & $0.01181-0.00861$ & $0.01263-0.03690$ & $0.00309-0.01829$ \\
\hline Slope at 95\% confidence interval (lower value-upper value) & $0.00409-0.00420$ & $0.09583-0.09890$ & $0.03099-0.03390$ & $0.04019-0.04145$ \\
\hline
\end{tabular}

Table 4: Accuracy results of sugammadex sodium and apremilast

\begin{tabular}{|c|c|c|c|}
\hline \multirow[t]{2}{*}{$\begin{array}{l}\text { \% Accuracy level for } \\
\text { sugammadex }\end{array}$} & $\begin{array}{l}\text { \% Recovery range for triplicate } \\
\text { preparations }\end{array}$ & \multirow[t]{2}{*}{$\begin{array}{l}\% \text { Accuracy level for } \\
\text { apremilast }\end{array}$} & $\begin{array}{l}\% \text { Recovery range for triplicate } \\
\text { preparations }\end{array}$ \\
\hline & $\%$ sugammadex sodium & & $\%$ apremilast \\
\hline 33 & $99.7-100.9$ & 33 & $99.3-100.3$ \\
\hline 100 & $100.1-100.5$ & 100 & $99.8-100.1$ \\
\hline 167 & $99.9-100.6$ & 167 & $99.8-100.2$ \\
\hline
\end{tabular}

Table 5: Accuracy results of riociguat and vorapaxar sulfate

\begin{tabular}{llll}
\hline $\begin{array}{l}\text { \% Accuracy level for } \begin{array}{l}\text { \% Recovery range for triplicate } \\
\text { riociguat }\end{array} \\
\text { preparations }\end{array}$ & $\begin{array}{l}\text { \% Accuracy level for vorapaxar sulfate } \\
\text { \% Riociguat }\end{array}$ & $\begin{array}{l}\text { \% Recovery range for triplicate } \\
\text { preparations }\end{array}$ \\
\hline 50 & $99.9-100.3$ & 50 & \% vorapaxar sulfate \\
100 & $99.7-99.9$ & 100 & $99.5-100.1$ \\
150 & $99.9-100.1$ & 150 & $99.8-100.3$ \\
\hline
\end{tabular}

Table 6: Robustness results for sugammadex sodium and apremilast

\begin{tabular}{lllll}
\hline Determination & $\begin{array}{l}\text { \% Assay of sugammadex } \\
\text { sodium at } \mathbf{2 0 8} \mathbf{~ n m}\end{array}$ & $\begin{array}{l}\text { \% Assay of sugammadex } \\
\text { sodium at } \mathbf{2 1 2} \mathbf{~ n m}\end{array}$ & $\begin{array}{l}\text { \% Assay of apremilast at } \\
\mathbf{2 2 8} \mathbf{~ n m}\end{array}$ & \% Assay of apremilast at 232 $\mathbf{~ m m}$ \\
\hline Determination-1 & 100.1 & 99.8 & 99.7 & 100.1 \\
Determination-2 & 99.9 & 100.0 & 100.0 & 99.8 \\
Determination-3 & 99.7 & 99.9 & 99.9 & 99.9 \\
Average & 99.9 & 99.9 & 99.9 & 99.9 \\
SD & 0.20 & 0.11 & 0.14 & 0.12 \\
\%RSD & 0.20 & 0.11 & 0.14 & 0.13 \\
\hline
\end{tabular}

SD: Standard deviation, RSD: Relative standard deviation

Table 7: Robustness results for riociguat and vorapaxar sulfate

\begin{tabular}{lllll}
\hline Determination & $\begin{array}{l}\text { \% Assay of riociguat at } \\
\mathbf{3 2 1} \mathbf{~ n m}\end{array}$ & $\begin{array}{l}\text { \% Assay of riociguat at } \\
\mathbf{3 2 5} \mathbf{~ n m}\end{array}$ & $\begin{array}{l}\text { \% Assay of vorapaxar sulfate } \\
\text { at } \mathbf{2 6 9} \mathbf{~ n m}\end{array}$ & $\begin{array}{l}\text { \% Assay of vorapaxar sulfate at } \\
\mathbf{2 7 3} \mathbf{~ n m}\end{array}$ \\
\hline Determination-1 & 99.8 & 100.0 & 99.9 & 99.9 \\
Determination-2 & 100.1 & 100.1 & 100.1 & 100.2 \\
Determination-3 & 99.9 & 99.9 & 100.0 & 100.0 \\
Average & 99.9 & 100.0 & 100.0 & 100.1 \\
SD & 0.17 & 0.12 & 0.07 & 0.15 \\
\%RSD & 0.17 & 0.12 & 0.07 & 0.15 \\
\hline
\end{tabular}

SD: Standard deviation, RSD: Relative standard deviation 
Table 8: Solution stability results of standard and control sample at RT and at refrigerated condition

\begin{tabular}{|c|c|c|c|c|c|}
\hline \multirow[t]{2}{*}{ Solution stability } & \multicolumn{5}{|c|}{$\%$ Assay results } \\
\hline & Initial & After 6 hrs & After 12 hrs & After 24 hrs & \% Difference \\
\hline \multicolumn{6}{|l|}{ Sugammadex sodium solution stability } \\
\hline$\%$ Assay of sample solution at RT & 100.2 & 100.0 & 99.6 & 99.8 & 0.6 \\
\hline$\%$ Assay of standard solution at $2-8^{\circ} \mathrm{C}$ & 100.0 & 100.0 & 99.8 & 99.6 & 0.4 \\
\hline$\%$ Assay of sample solution at $2-8^{\circ} \mathrm{C}$ & 100.2 & 99.8 & 99.6 & 99.4 & 0.8 \\
\hline \multicolumn{6}{|l|}{ Apremilast solution stability } \\
\hline$\%$ Assay of standard solution at RT & 99.8 & 99.6 & 99.4 & 99.3 & 0.5 \\
\hline$\%$ Assay of sample solution at RT & 100.0 & 99.5 & 99.3 & 99.3 & 0.7 \\
\hline$\%$ Assay of standard solution at $2-8^{\circ} \mathrm{C}$ & 99.8 & 99.4 & 99.4 & 99.6 & 0.4 \\
\hline$\%$ Assay of sample solution at $2-8^{\circ} \mathrm{C}$ & 100.0 & 99.6 & 99.8 & 99.6 & 0.4 \\
\hline \multicolumn{6}{|l|}{ Riocuguat solution stability } \\
\hline$\%$ Assay of standard solution at RT & 100.0 & 99.8 & 99.7 & 99.5 & 0.5 \\
\hline$\%$ Assay of sample solution at RT & 99.9 & 99.7 & 99.9 & 99.7 & 0.2 \\
\hline$\%$ Assay of standard solution at $2-8^{\circ} \mathrm{C}$ & 100.0 & 99.7 & 99.7 & 99.5 & 0.5 \\
\hline$\%$ Assay of sample solution at $2-8^{\circ} \mathrm{C}$ & 99.9 & 99.9 & 99.7 & 99.9 & 0.2 \\
\hline$\%$ Assay of standard solution at RT & 100.1 & 99.8 & 99.7 & 99.5 & 0.6 \\
\hline$\%$ Assay of sample solution at RT & 100.1 & 100.0 & 99.8 & 100.0 & 0.3 \\
\hline$\%$ Assay of standard solution at $2-8^{\circ} \mathrm{C}$ & 100.1 & 100.0 & 99.5 & 99.8 & 0.6 \\
\hline$\%$ Assay of sample solution at $2-8^{\circ} \mathrm{C}$ & 100.1 & 100.0 & 99.8 & 99.8 & 0.3 \\
\hline
\end{tabular}

RT: Room temperature

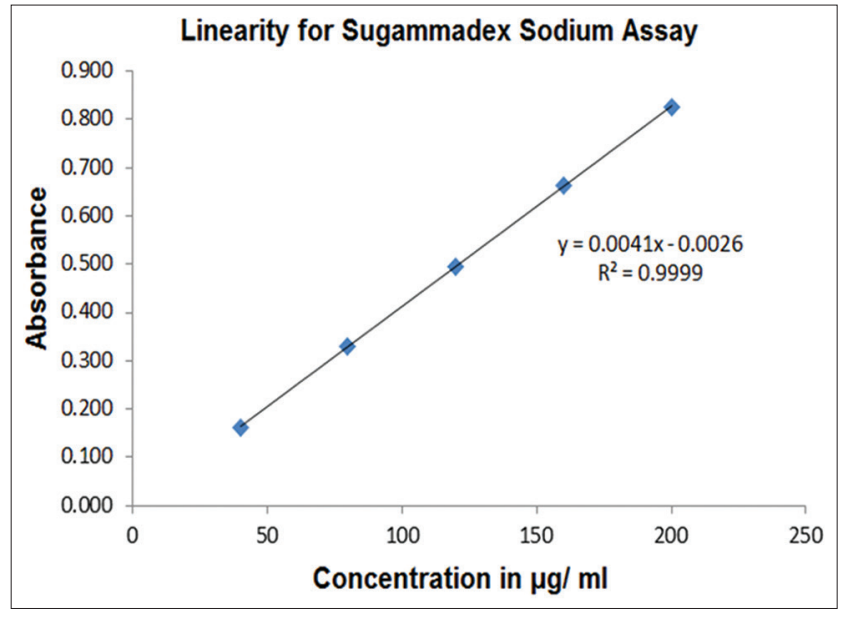

Fig. 15: Linearity graph of sugammadex sodium

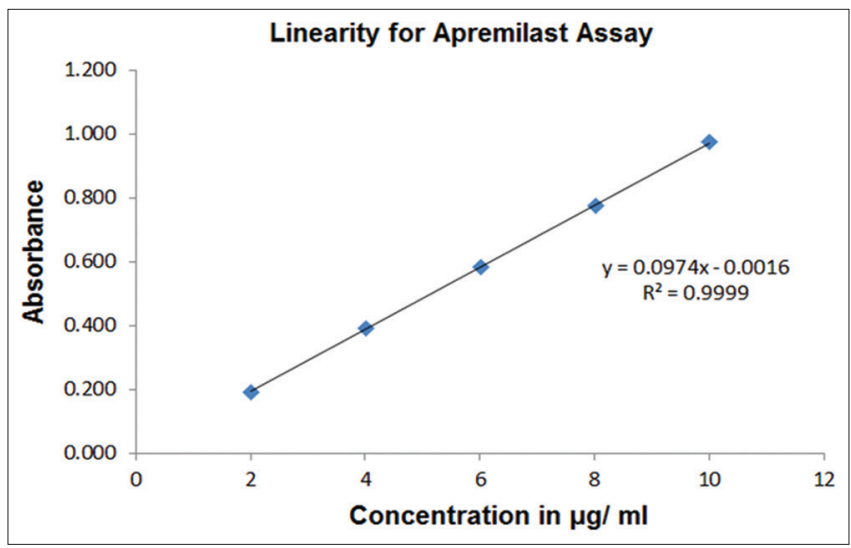

Fig. 16: Linearity graph of apremilast

\section{CONCLUSIONS}

Simple, precise and economical UV-visible spectrophotometric method has been developed for the quantitative estimation of sugammadex

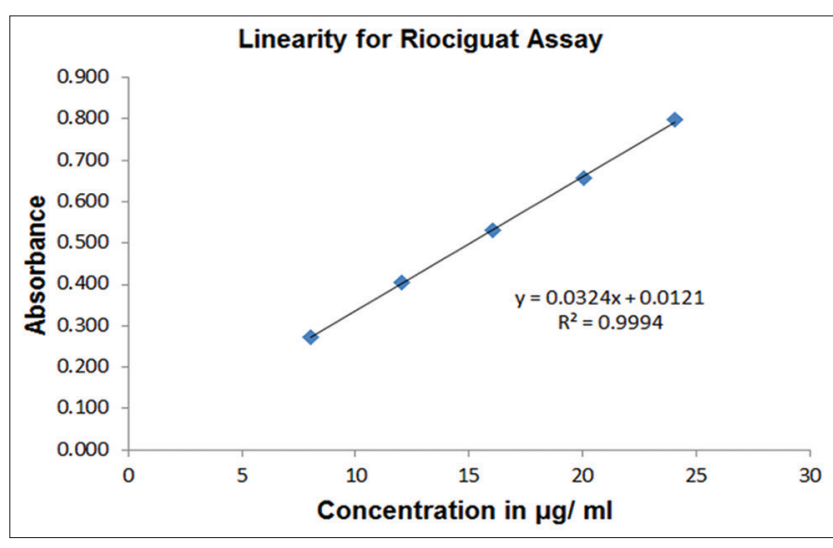

Fig. 17: Linearity graph of riociguat

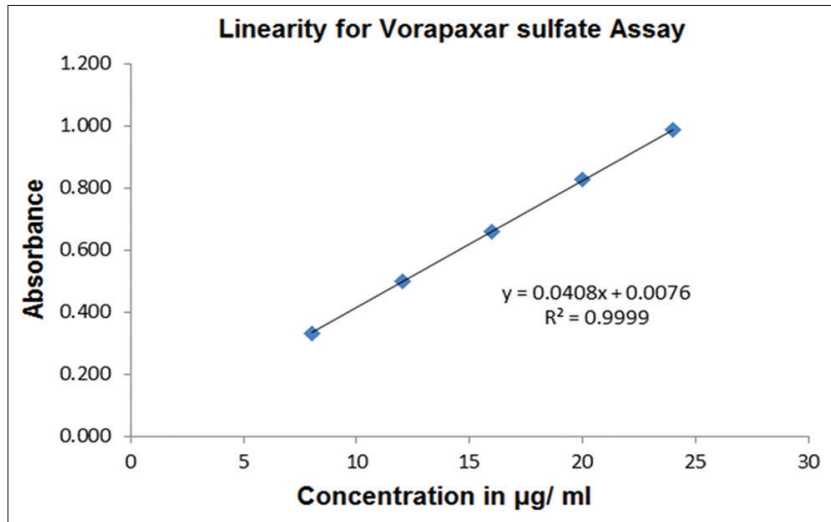

Fig. 18: Linearity graph of vorapaxar sulfate

sodium, apremilast, riociguat, and vorapaxar sulfate in its API form. Method is validated as per the ICH guidelines and also the developed method is robust with respect to wavelength variation to the original wavelength. The developed method can be used for the quantification of sugammadex sodium, apremilast, riociguat, and vorapaxar sulfate drug substances in routine analysis. 


\section{ACKNOWLEDGMENTS}

The authors would like to thank Department of Inorganic and Analytical Chemistry, Andhra University, Vishakhapatnam, Andhra Pradesh, India, for their encouragement.

\section{REFERENCES}

1. Naguib M, Brull SJ. Sugammadex: A novel selective relaxant binding agent. Expert Rev Clin Pharmacol 2009;2(1):37-53

2. Available from: http://www.drugbank.ca/drugs/DB06206.

3. Assessment Report for Bridion from European Medicines Agency (EMA). Available from: http://www.ema.europa.eu/docs/en_GB/ document_library/EPAR_-_Public_assessment_report/human/000885/ WC500052309.pdf.

4. Available from: https://www.en.wikipedia.org/wiki/Apremilast.

5. Available from: https://www.tga.gov.au/sites/default/auspar-apremilast151022-pi.docx.

6. Available from: https://www.en.wikipedia.org/wiki/Riociguat.

7. Available from: http://www.ema.europa.eu/docs/en_GB/document library/EPAR - Public assessment report/human/002737/ WC500165036.pdf.

8. Available from: https://www.en.wikipedia.org/wiki/Vorapaxar

9. Available from: http://www.ema.europa.eu/docs/en_GB/document library/EPAR___Summary_for_the_public/human/002814/ WC500183332.pdf

10. Available from: http://www.ema.europa.eu/docs/en_GB/document library/EPAR - Public assessment report/human/002814/ WC500183331.pdf.

11. Kaihe X, Ma X, Cao N, Lei L, Lili S, Qiaogen Z, et al. Identification, characterization and HPLC quantification of impurities in apremilast. Anal Methods 2016;8:1889-97.

12. Sirisha P, Sharma JV, Nikhitha S, Likitha R, Uday KB, Durga PS, et al. Method development and validation of Riocuguat by RP-HPLC. Pharm Int J Adv Pharm Sci 2016;7(2):3060-2.

13. USPC. United States Pharmacopeia 37, National Formulary 32. Rockville, MD, USA: United States Pharmacopeial Convention Inc.; 2014.

14. European Pharmacopoeia 8.7.

15. ICH, Q2(R1). Harmonized Tripartite Guideline, Validation of Analytical Procedures: Text and Methodology in Proceedings of the International Conference on Harmonization of Technical Requirements for Registration of Pharmaceuticals for Human Use; 2005.

16. Ashok CV, Sailaja BB. Method development and validation of assay and dissolution methods for the estimation of Daclatasvir in tablet dosage forms by reverse phase HPLC. Eur J Pharm Med Res 2016;3(7):356-64

17. Ashok CV, Sailaja BB, Praveen KA. Development and validation of a dissolution method for frovatriptan tablets by reverse phase UPLC. Int J Pharm Pharm Sci 2015;7(4):125-30.

18. Ravichandran V, Shalini S, Sundramand KM, Rajak H. Validation of analytical methods-strategies and importance. Int J Pharm Pharm Sci 2010;2(3):18-22.

19. United States Food and Drug Administration. Guidance for Industry: Analytical Procedures and Methods Validation: Chemistry, Manufacturing, and Controls Documentation. Rockville, MD: Draft Guidance, USFDA; 2001.

20. USP. Chapter 1225. Validation of compendial methods. United States Pharmacopeia 37, National Formulary 32. Rockville, MD, USA: The United States Pharmacopeial Convention Inc.; 2014. 